\title{
Liberating cohesin from cohesion
}

\author{
Kerry Bloom \\ Department of Biology, University of North Carolina at Chapel Hill, Chapel Hill, North Carolina 27599, USA
}

Cohesin was identified through its major role in holding sister chromatids together. We are learning through analysis of cohesin and other members of the protein family (SMC [structural maintenance of chromosomes]) and their regulators that these ring complexes contribute to chromosome organization and dynamics throughout the cell cycle. We need to consider not only how ring complexes are regulated but how they interact with their fluctuating chromatin substrate.

Cohesin is a ring complex comprised of coiled-coil proteins SMC1 (structural maintenance of chromosomes 1) and $S M C 3$, kleisin $(S c c 1 / M c d 1)$, and HEAT repeat protein Scc3. The original phenotype and nom de plume is its function in promoting sister chromatin cohesion. SMCs are part of a larger family of ring complexes, including condensin $(S M C 2,4)$ and the SMC5,6 complex that participates in a number of DNA transactions, including replication, repair, chromosome condensation, and segregation. The binding and release of the SMC1,3 cohesin complex is performed by a number of factors that promote either cohesion (including ECO1 [ESCO1/2], an acetyltransferase functioning through ring closure, and sororin) or cohesion destabilizers (such as WAPL via ring opening and the release factor PDS5 [PDS5A/B]). As we explore the genome in time and space, we are coming to appreciate that these ring complexes exhibit a diverse array of functions and significantly more functional overlap than their names imply.

Kawasumi et al. (2017) explore ESCO1/2 function through targeted mutations in chicken DT40 cells, where they discovered roles for these acetyltransferases in establishing chromosome territories during interphase and centromere organization in metaphase. These functions do not rely on cohesin acetylation (K105, K106) and force us to broaden our thinking of how protein ring complexes and their regulation might function in higher-order chromosome organization.

The first step in building intuition is to consider how the behavior of the substrate (i.e. DNA) affects the function of these ring complexes. Chromosomes ( 50:50 pro-

[Keywords: cohesin acetyltransferases; ESCO1/2; centromere; chromatin territories; chromosome segregation; sister chromatid cohesion] Corresponding author: kerry_bloom@unc.edu

Article is online at http://www.genesdev.org/cgi/doi/10.1101/gad.309732. 117.
tein:DNA) are long chain polymers comprising $~ 10 \%$ the mass of the nucleus. They are floppy, defined by the very short length scale over which they tend to be straight (50-nm Lp [persistence length] vs. 6-mm Lp for microtubules). Depictions of DNA as linear fibers for didactic purposes are not useful for mechanistic studies. The physics of long chain polymers in a highly viscous confined environment reveal that interchromosomal interactions are thermodynamically disfavored, biasing each chain to adopt individual random coils. The interaction with self can be observed in experimentally obtained contact probability maps from genome-wide chromosome conformation studies (Fudenberg and Mirny 2012; Dekker et al. 2013). A secondary organizing principle is the formation of intrachromosomal loops, such as the large enhancermediated loops stabilized by CTCF and cohesin. Loops are a natural consequence of the entropic fluctuations of long chains (Vasquez et al. 2016). Thinking of the genome as a ball of yarn, loops will form as the result of random motions of the polymer chain. As one adds energy-fueled machines such as condensin and cohesin, loops can be extruded, tuned, and stabilized for specific metabolic functions.

The cohesin ring must be considered in the context of its substrate. In the case of a DNA translocase ring complex such as condensin (Terakawa et al. 2017), walking along a floppy substrate results in extrusion of DNA loops (Lawrimore et al. 2017). In the case of diffusible rings such as cohesin, the rings can tether two strands. This is the canonical cohesion function between sister chromatids but can just as well be tethers within a single strand (i.e., loop) or a single diffusible ring. Such tethers also promote centromere clustering between chromosomes (Rabl organization). Less intuitive is the behavior of slip link rings in a network. Polymer networks (i.e., the genome) can be cross-linked via fixed connectors through which the DNA chain cannot slide or slip links that allow chain slippage. Slip link gels, known as polyrotaxane gels (Okumura and Ito 2001), undergo changes in volume over orders of magnitude while maintaining morphology. As the state of the polymer changes (e.g., hydration shell or phase state), slip links accommodate changes in the material

(C) 2017 Bloom This article is distributed exclusively by Cold Spring Harbor Laboratory Press for the first six months after the full-issue publication date (see http://genesdev.cshlp.org/site/misc/terms.xhtml). After six months, it is available under a Creative Commons License (Attribution-NonCommercial 4.0 International), as described at http:// creativecommons.org/licenses/by-nc/4.0/. 
property of the chain, for instance, to equilibrate tension throughout the network. Thermodynamic simulations of a chromatin loop with and without cohesin rings illustrate mechanisms by which diffusible rings restrict fluctuation of the chromatin backbone as well as the area that the chromatin chain occupies (Lawrimore et al. 2016).

What the Kawasumi et al. (2017) study shows is that cohesin rings and their regulation participate in genome organization as cells cycle through division. In interphase, ESCO1/2 together with Wapl work to reduce the amount of cohesin (more cohesin in the mutants). In simulation, rings that link nonadjacent genomic sites are a way to compact and partition regions such as the nucleolus (Hult et al. 2017). Thus, ESCO1/2,Wapl modifications function to expand the genome, likely increasing exploration, loop size, and number/frequency of interactions via reduction in cohesin/substrate cross-links.

In metaphase, cohesin plays a central role in centromere organization. The centromere is the region of the chromosome that dictates kinetochore assembly and microtubule attachment for chromosome segregation. An outstanding question in the field is how tension is generated between sister kinetochores that can be on the order of $1 \mu \mathrm{m}$ apart. Kawasumi et al. (2017) show that the distance between sister centromeres is increased in esco 2 mutants. Thus, cohesin is required for centromere integrity. In budding yeast, where the centromere is defined at the DNA sequence level, cohesin together with condensin provide a mechanism to increase the density of loops (Lawrimore et al. 2015, 2016). Upon biorientation, the loops adopt a bottle brush configuration surrounding a DNA axial core. The bottle brush is stiff due to side loops restricting the number of thermodynamic states that the axial core can adopt. In this way, sister centromeres are "pushed" apart, biasing kinetochores to the surface of the chromosome. Kawasumi et al. (2017) show that ESCO1/2 modification of cohesin plays a role in regulating this function in mammalian cells as well.

Mutations in ring complexes (cohesin and condensin) have been identified in a number of developmental disorders and disease states (Zakari et al. 2015). Considering the diversity of their function, it is a major challenge to identify specific protein deficiencies that map to specific disorders. Targeted mutations with critical quantitative analysis as performed in Kawasumi et al. (2017) exemplify how we make progress in this exciting yet nonintuitive field.

\section{References}

Dekker J, Marti-Renom MA, Mirny LA. 2013. Exploring the three-dimensional organization of genomes: interpreting chromatin interaction data. Nat Rev Genet 14: 390-403.

Fudenberg G, Mirny LA. 2012. Higher-order chromatin structure: bridging physics and biology. Curr Opin Genet Dev 22: 115-124.

Hult C, Adalsteinsson D, Vasquez PA, Lawrimore J, Bennett M, York A, Cook D, Yeh E, Forest MG, Bloom K. 2017. Enrichment of dynamic chromosomal crosslinks drive phase separation of the nucleolus. Nucleic Acids Res 45: 11159-11173.

Kawasumi R, Abe T, Arakawa H, Garre M, Hirota K, Branzei D. 2017. ESCO1/2's roles in chromosome structure and interphase chromatin organization. Genes Dev (this issue) doi: 10.1101/gad.306084.117.

Lawrimore J, Vasquez PA, Falvo MR, Taylor RM II, Vicci L, Yeh E, Forest MG, Bloom K. 2015. DNA loops generate intracentromere tension in mitosis. J Cell Biol 210: 553-564.

Lawrimore J, Aicher JK, Hahn P, Fulp A, Kompa B, Vicci L, Falvo M, Taylor RM II, Bloom K. 2016. ChromoShake: a chromosome dynamics simulator reveals that chromatin loops stiffen centromeric chromatin. Mol Biol Cell 27: 153-166.

Lawrimore J, Friedman B, Doshi A, Bloom K. 2017. RotoStep: a chromosome dynamics simulator reveals mechanisms of loop extrusion. Cold Spring Harb Symp Quant Biol doi: 10.1101/sqb.2017.82.033696.

Okumura Y, Ito K. 2001. The polyrotaxane gel: a topological gel by figure-of-eight cross-links. Adv Mater 13: 485-487.

Terakawa T, Bisht S, Eeftens JM, Dekker C, Haering CH, Greene EC. 2017. The condensin complex is a mechanochemical motor that translocates along DNA. Science 358: 672-676.

Vasquez PA, Hult C, Adalsteinsson D, Lawrimore J, Forest MG, Bloom K. 2016. Entropy gives rise to topologically associating domains. Nucleic Acids Res 44: 5540-5549.

Zakari M, Yuen K, Gerton JL. 2015. Etiology and pathogenesis of the cohesinopathies. Wiley Interdiscip Rev Dev Biol 4: 489-504. 


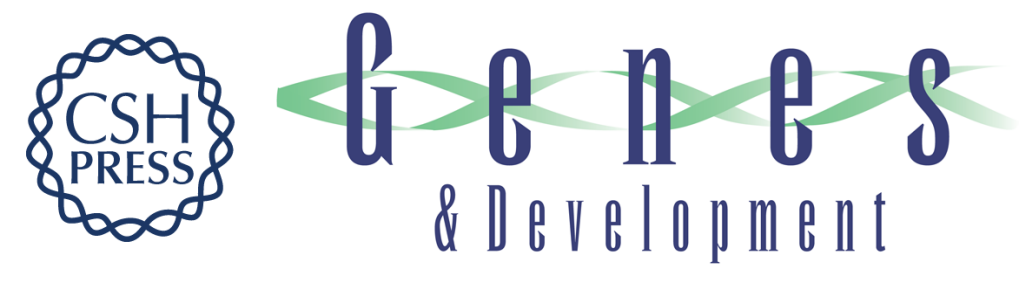

\section{Liberating cohesin from cohesion}

Kerry Bloom

Genes Dev. 2017, 31:

Access the most recent version at doi:10.1101/gad.309732.117

Related Content ESCO1/2's roles in chromosome structure and interphase chromatin organization Ryotaro Kawasumi, Takuya Abe, Hiroshi Arakawa, et al. Genes Dev. November , 2017 31:2136-2150

References This article cites 11 articles, 5 of which can be accessed free at: http://genesdev.cshlp.org/content/31/21/2113.full.html\#ref-list-1

Articles cited in:

http://genesdev.cshlp.org/content/31/21/2113.full.html\#related-urls

Creative This article is distributed exclusively by Cold Spring Harbor Laboratory Press for the first Commons License six months after the full-issue publication date (see http://genesdev.cshlp.org/site/misc/terms.xhtml). After six months, it is available under a Creative Commons License (Attribution-NonCommercial 4.0 International), as described at http://creativecommons.org/licenses/by-nc/4.0/.

Email Alerting Receive free email alerts when new articles cite this article - sign up in the box at the top Service right corner of the article or click here.

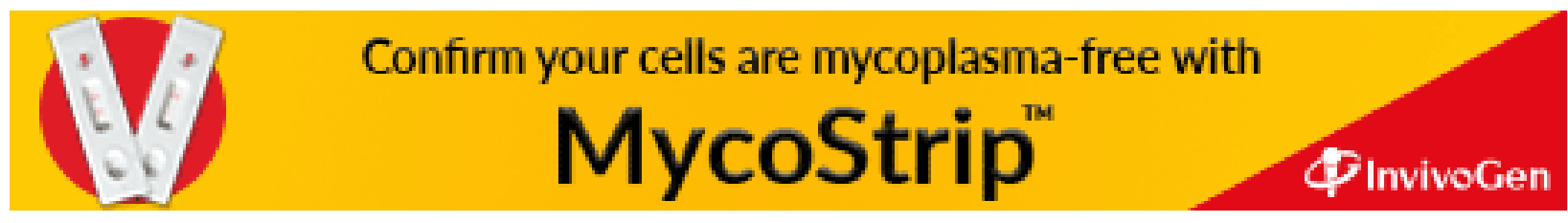

